\title{
Soil Toxicity in the Dorset Heaths
}

\begin{abstract}
A MEETING of the British Ecological Society, presided over by Prof. A. G. Tansley, was held on April 20, in the Department of Botany, Bedford College, Regent's Park, London, N.W.1. The entire meeting was given to consideration of the problems of soil toxicity and its amelioration in the Dorset heaths. The researches now in progress have come about as a result of observations and experiments initiated by Dr. M. C. Rayner in the Wareham neighbourhood in 1931 on the lands of the Forestry Commission now known as Wareham Forest.

A considerable tract of country around the town of Wareham in Dorset is occupied by heathland. Certain areas of this were acquired by the Forestry Commission and sown with several species of pine in 1924-27. These original sowings gave very poor results, the seedlings for the most part showing no growth or dying outright. In addition, there were many puzzling inconsistencies of behaviour.

The meeting was opened by an informal account by Prof. Neilson Jones of some of the characteristics, including that of apparent toxicity, associated with Wareham soil, and was followed by a general summary by Dr. Rayner of the field and laboratory researches at Wareham Forest that have led to the present situation. Some of the exhibits, relating to mycological and mycorrhizal problems arising from the field experiments, have an important bearing on the nutrition and healthy growth of conifers in
\end{abstract}

cultivation, for example, those on Sitka spruce and Lawson's cypress.

The accounts of the work were supplemented by a large number of well-displayed demonstrations illustrating various phases of the research work in progress. Among these were demonstrations of the inhibition of seedling and fungal growth by soil factors, growth effects produced by the addition of raw cellulose to soils, epinastic curvature reactions induced by soil constituents, the incidence of 'fused needle' disease, and the effects on seedling growth produced by soil inoculation with humus or mycelium from pure cultures.

Also illustrated were the remarkable effects on growth brought about by the use of certain organic composts on Wareham soil, with some of the evidence supporting the hypothesis that led to their use and now put forward to interpret their action. Pure cultures of a number of mycorrhizal and associated soil fungi were displayed.

A general discussion followed inspection of the demonstrations, in which a number of visitors and members of the Society took part.

In his concluding remarks, Prof. Tansley pointed out that a meeting such as that just held, in which the Society visited an institution to hear about the research work in progress there, was an innovation; the results of the experiment led him to hope that other meetings of the kind would be arranged in the near future.

\section{Faunistic and Hydrographic Changes}

\section{By B. Storrow, Dove Marine Laboratory, Cullercoats, Northumberland}

$\mathrm{T}$ HE following faunistic records are of interest in connexion with recent hydrographic changes as described in the reports of the International Council for the Exploration of the Sea. Abnormal activity of Atlantic waters around the north of Scotland will bring oceanic and western species into the northern North Sea. When this activity is followed by a southerly extension of the influence of the Norwegian sea the recent additions to the fauna can be expected to retreat to the Atlantic or to move southwards before the influence of the colder waters. In this southerly movement before the advance of cold conditions they will be followed by the fauna of the colder waters. Records of a mixed fauna may be found still farther south after a suitable interval. The above outlines the probable cause for the following records which have been obtained for the Northumberland coast. Unless otherwise stated, the specimens mentioned have been obtained from North Shields trawlers.

Geryon tridens Krøyer. 25-30 years ago this crab was commonly called the Fair Isle pilot by North Shields skippers, who did not find it in their trawls until reaching the vicinity of Fair Isle. To the best of our knowledge it has not been recorded for the waters off Northumberland. The first specimen was obtained April 29, 1935, 31 miles N.E. $\frac{1}{2}$ N. of the Tyne, which is to the east of Coquet Island. The second specimen was found on March 10, 1936, and the trawler had been fishing 10 miles N.E. $\frac{1}{2}$ N. off the Tyne. No further records were obtained until October 1937, and from then until the end of the year 49 specimens were brought to the Laboratory from trawlers fishing off our coast. Some of these crabs are living in our tanks.

Chimaera monstrosa L. As a general rule, North Shields trawlers do not get the rat-fish until reaching the latitude of Aberdeen or thereabouts, and then not frequently. One was taken $10 \frac{1}{2}$ miles N.N.E. of the Tyne, January 22, 1938.

Urophycis blennoides (Brünnich). The greater fork-beard has never been a local fish and its presence in the catch of a North Shields trawler was associated with fishing in more northerly waters and often in the vicinity of the Norwegian deep water. One was caught 14 miles east-north-east of the Tyne, June 15 , 1936.

Pristiurus melastomus (Rafinesque). According to Smitt the black-mouthed dogfish has a wide range and has been taken occasionally off the Norwegian 
coast and in the Skager Rack and Cattegat. One was taken in 42 fathoms east of Coquet Island, April 30, 1937.

Centrolophus niger (Gmelin). The black-fish of Couch is considered a fish of the Mediterranean and Atlantic. Occasional stragglers have been taken off our south coast and Day refers to specimens from the Northumberland and Yorkshire coasts. One of $56 \mathrm{~cm}$. was taken on Berwick Bank, October 25, 1937.

Cetorhinus maximus (Gunner). It is generally supposed that the basking shark migrates northwards along the Atlantic seaboard as far as the Norwegian coast after its appearance off the west coast of Ireland in spring. Occasionally it enters the North Sea. One, $10 \mathrm{ft} .11 \frac{1}{2} \mathrm{in}$. in length, was caught in salmon nets, 2 miles off Souter, on June 13, 1934 .
Ctenolabrus rupestris (L.). The goldsinny is found along the Atlantic coasts of Europe from the Mediterranean to Trondheim and in the southern Baltic. It has been recorded for Northumberland and Yorkshire, but not in our time. A specimen caught on July 3, 1935, 20 miles north-north-east of the Tyne, is living in the aquarium. Another was picked up on Whitley sands, January 31, 1937.

Maurolicus muelleri (Gmelin). The pearl-side has a wide distribution. According to Smitt, it has been found on both sides of the Atlantic and from the coast of Finmark to that of Sweden. It also enters the North Sea. It is far from common off our coast. Three specimens have been picked up on the sands of Cullercoats and Whitley Bay recently in March and April; one in 1936 and two in 1937.

\section{Science and Industry}

\begin{abstract}
A SERIES of lectures arranged by the London B Branch of the Association of Scientific Workers on the subject of science and industry has recently come to its conclusion. These lectures were arranged by the Association with the object of directing attention to the application of scientific methods and developments in industry, and the possibility of increased application; the allied question of the organization of research; and the question of the best types of scientific education to fit men for technical positions in industry.

The first lecture was given by Sir Richard Gregory. $\mathrm{He}$ opened with an enumeration of some of the outstanding benefits that science has conferred on society, and showed how the developments of industry have depended upon the developments of creative science. The extent, however, to which scientific discovery is used for industrial progress depends upon the capacity of industry to understand the results of research and the power to use them. The general principle that expenditure on science is a profitable investment may be said to have been conceded, but as yet science is not used as fully as it may be. Forty years ago the expenditure of the British Government on scientific investigation was about $£ 45,000$; at the present time the total amount is nearly two millions, of which the Department of Scientific and Industrial Research administers about $£ 600,000$. Sir Richard quoted a memorandum presented by the Parliamentary Science Committee, and supported its argument that the provision for scientific and industrial research in Great Britain is inadequate and that a bolder and broader financial scheme is needed.
\end{abstract}

Sir Richard went on to plead for the employment of men with scientific training and knowledge as directors and administrators. Industry suffers from administ ators who have not a scientific outlook and do not realize the value of long-sustained expenditure on scientific research, although he admitted that it is difficult to find men who combine specialized know. ledge on scientific and technical subjects with organizing or administrative capacity.

Sir John Russell traced the application of science to agriculture from the early investigation into artificial manures carried out on the same land now occupied by the Experimental Station at Rothamsted to the present day, when such research demands the knowledge of chemists, physicists, botanists, biochemists, pathologists, etc. The development of agriculture has not been devoid of chance discoveries, particularly in the development of wheat and in the use of such things as Bordeaux mixture, devised to scare away predatory boys. There has, however, been great advances in the knowledge and control of the processes of Nature as a result of the patient detailed work that has been carried out. Besides the effect of the well-known artificial manures, it has been discovered of recent years that traces of certain inorganic salts such as the compounds of cobalt and boron have a marked effect on the plant life and the subsistent animal life.

Under the title of "Science in the Chemical Industry", Major F. A. Freeth indulged in alternate attacks on and justification of the existence of industrial scientific workers. The attacks were, however, more of the nature of constructive criticism. That the existence of men of science is justified there is no doubt; but there is doubt whether they have the right attitude to their tasks. Men of science as a body lack rhetoric-they do not know how to capture the enthusiasm of the general public.

The chemical industry itself is the only industry that takes its name from the science on which it is based. It should properly be called the 'molecular industry', for it is chiefly the scientific study of the behaviour of molecules which forms the basis on which the large industries are built. Some of the heavy chemical industries date back for decades, but the modern organic chemist owes everything to the patient hard work of investigators which is continuing all the time. Fundamental scientific theory is required for any new development in the chemical industry, but before it can be put into practice it must be translated into terms of large-scale plant and teams of men, and there is often a considerable timelag between the adoption of a new method and its achievement in practice.

Dr. E. A. Rudge spoke on the subject of training for the chemical industry and chemical engineering; and described an investigation he had conducted to find out the requirements of a number of chemical 